\title{
Opportunities and Challenges for Regional Financial Development under the Background of "One Belt One Road"
}

\author{
Han Gang \\ Master degree graduate \\ Renmin university of China \\ Beijing \\ China \\ Si Rijimoleng \\ Ph.D. Candidate \\ Central University of Finance and Economics \\ Department of Economics \\ Beijing \\ China
}

\begin{abstract}
Under the guidance of the "One Belt One Road" (B\&R) strategy, china has carried out a lot of cooperation with other countries those along the $B \& R$ in the areas of transportation infrastructure, trade and investment, energy cooperation, regional integration and $R M B$ internationalization. It is conducive to made great progress for regional economic and financial development and achieve win-win cooperation goals. The differences in Resource endowment, economic development level, political history among different countries leading to the different level of economic and financial development. It has negative impact on regional cooperation. Therefore, this paper analyzes the opportunities and challenges of regional financial development under the background of "One Belt One Road" and puts forward relevant policy suggestions.
\end{abstract}

Keywords: One Belt One Road; Regional Finance; Opportunities and Challenges

\section{Introduction}

Under the guidance of the "One Belt One Road"(B\&R)strategy, china has carried out a lot of cooperation with other countries those along the $\mathrm{B} \& \mathrm{R}$ in the areas of transportation infrastructure, trade and investment, energy cooperation, regional integration and $\mathrm{RMB}$ internationalization. It is conducive to made great progress for regional economic and financial development and achieve win-win cooperation goals. Since the implementation of "One Belt One Road" development strategy, more than 30 countries have signed cooperation with China, and 20 countries have launched international production capacity cooperation. According to the statistics of the ministry of commerce, China's investment in "One Belt One Road" countries accounted for 12\% of the total foreign direct investment in the same period. It has reached $\$ 51.1$ billion. A total of 12,500 new contracts were signed with countries along the B\&R line and the total amount is $\$ 279$ billion. As the core of modern economy, finance plays a key role in optimizing the allocation of resources in the construction of B\& $\mathrm{R}$. With the deepening of investment and trade between countries along the belt and road, financial cooperation between different countries is affected by the system and development level and faces many new challenges. In this context, the innovation of regional financial service mode not only enhances the participation degree of regional financial cooperation, but also helps to reduce financial risks and realize the goal of financial cooperation and interconnection. The combination of deregulation, globalization and information technology has changed the performance, strategy and structure of individual Banks (Colwell, 1991; Danton, 1992; Gorton and Rosen, 1995).The deregulation of America's Banks created new opportunities for regional Banks to compete with other state Banks (Harrington and Warf, 1995).Information technology makes strategic innovation possible. For example, IT and novel marketing strategies create opportunities for regional financial institutions to provide financial services, through Shared technology platforms, such as ATMs and payment processing systems. 
The cooperation between regional financial institutions requires the establishment of information networks of policies, finance and other aspects. Individual bank clients of regional financial institutions are creating new organizational structures that are managed and coordinated globally through the network information system. These structures often involve multiple decision-makers with complex interdependencies in different regions. (Javetski et al., 1995)."One Belt One Road" countries are rich in natural resources, but most of them suffer from economic development bottlenecks due to the lack of infrastructure, human capital, technology and capital. It needs the Innovation in financial services models. Huoxuewu et al. (2016) believe that the B\&R strategy not only enhances international trade cooperation, but also promotes the development of domestic trade. Under the changing circumstances of domestic and international trade environment, financial institutions should innovate in products, channels, models and organizations to meet international and domestic trade needs. Xia caiyun (2016) analyzed the current situation of regional financial cooperation in China under the background of B\&R, believe that regional financial cooperation has problems such as imbalance of financial development in the Midwest regions of China, the financial development of countries along the $B \& R$ is unbalanced, the national sovereign credit rating varies widely and lack of risk prevention mechanismetc. At the same time, some Suggestions are put forward, such as, B\&R financial cooperation need to establish a free trade area of regional financial cooperation, Regional financial market cooperation, promoting the two-way entry of financial institutions and the cooperation of regional financial supervision etc. In this paper, we randomly choose Mongolia, Singapore, Malaysia, Turkey, India, Kazakhstan, Russia and Bulgaria as a representative from the B\& Rradiation area: the association of southeast Asian nations, west Asia, South Asia, central Asia and Europe. And analyzes the opportunities and challenges of regional financial development under the background of "One Belt One Road" and puts forward relevant policy Suggestions.

\section{Opportunities for regional financial development under the background of $B \& R$}

The rapid economic development of the 21 st century, economic regional cooperation and the realization of winwin cooperation is increasingly prominent. China advocates "One Belt One Road" development strategy, with the theme of peaceful development and win-win cooperation, and actively engaged in economic cooperation with countries along the ancient silk road, establish a partnership for economic cooperation and work together to build a community of mutual trust, integration and inclusiveness in politics, economy and culture. "One Belt One Road" development strategy thoughts originated in 2013, during a speech in Kazakhstan and Indonesia, chairman xijinpingputs forward the strategic initiatives of "silk road economic belt" and "21st century maritime silk road" respectively. On March 28, 2015, authorized by the state council, the national development and reform commission, the ministry of foreign affairs and the ministry of commerce jointly issued the "push to build the silk road economic belt and the 21st century the vision and action of the Marine silk road", announce China's "One Belt One Road" development strategy to the comprehensive development stage. It is pointed out in the outline of China's 13th five-year plan that China-south China peninsula, new Eurasian land bridge, China-Mongolia-Russia, china-brazil, china-central Asia-west Asia, and Bangladesh, China and India, are among the six-major international economic cooperation corridors. The economic cooperation strategy is mainly composed of five aspects: policy, facilities, trade, capital and the feelings of citizen. The implementation of B\&R development strategy has provided the economic and financial development stage for countries along the $\mathrm{B} \& \mathrm{R}$ and provided the possibility for further development of regional finance.

(1) the development of foreign-related financial settlement business is the space for the development of regional financial services

The development strategy of B\&R has brought a grand stage for China's cooperation in international investment, international trade and international production capacity and financial innovation. There is a certain gap between the economic development and industrial structure of the countries along the development strategy of B \& R. With China's opening to the outside world, China's international trade has increased continuously. The implementation of $B \& R$ development strategy has promoted the transnational regional cooperation of trade and promoted the international cooperation of production capacity. The rapid development of international trade has brought new challenges to the international business services of financial institutions and promoted the product innovation of financial institutions. At the same time, the continuous innovation of financial institutions will further promote international cooperation in trade. Zhang min said that the multi-industry integration of Internet, finance, financial leasing and equipment manufacturing industry have provided more market for equipment manufacturing. 
With the development of economic and finance, the foreign financial transactions of various countries have been developing continuously. Foreign direct investment business is one of the typical examples. Foreign direct investment refers to the direct investment equity flows in the economy. It is the sum of equity capital, reinvestment and other capital. Direct investment is a kind of cross-border investment related to the residents of an economy, which has a control or significant impact on the management of enterprises residing in another economy. From the perspective of foreign direct investment in foreign countries from 2007 to 2015, the net inflow of foreign investment in each country is different, but there is a growing trend.

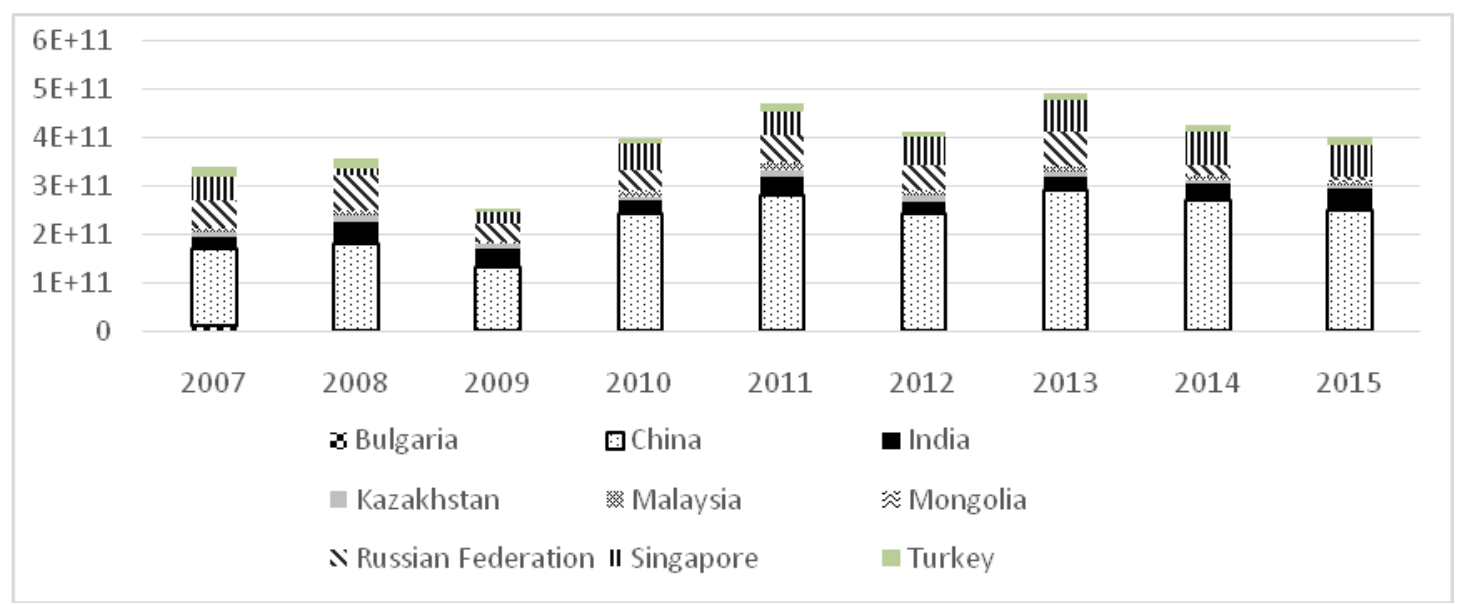

From figure 1 below, we can see that china has the largest net inflow of foreign investment, with a peak of almost $\$ 300$ billion. Figure 1 net foreign investment flows in 9 countries along the B\&R

Source: world bank official website

Since the net inflow of foreign investment in China is relatively large, it is difficult to see the specific situation of the other eight countries. In figure 2, China is removed and compared with the net inflow of foreign investment in the other eight countries. The net inflow of foreign investment in Mongolia was found to be relatively low, reaching a peak of $\$ 4.2$ billion between 2007 and 2015.After the 2008 financial crisis, Singapore's net foreign investment inflows rose to $\$ 23.8$ billion, from $\$ 12.2$ billion, and remained relatively high. By 2013 , it reached a peak of $\$ 69.2$ billion, maintaining a level of more than 60 billion over the last two years, with relatively small fluctuations. Russia is easily affected by the international market country, from the data clearly see its foreign investment data influenced by macroeconomic fluctuations, affected by the financial crisis of 2008, the foreign investment inflows fell sharply. Since 2009, it has gradually increased, and since the economic downturn in recent years has led to a decline in the net inflow of foreign investment. The net inflow of foreign investment in India between 2007 and 2015 was between 200 and 40 billion dollars, and the fluctuation range was not very large. In Bulgaria, Malaysia, Turkey and Kazakhstan there was a consistent wave of volatility.Net outflow of foreign investment gradually increased.

Figure 2 net foreign investment flows in 8 countries along the B\&R

Source: world bank official website

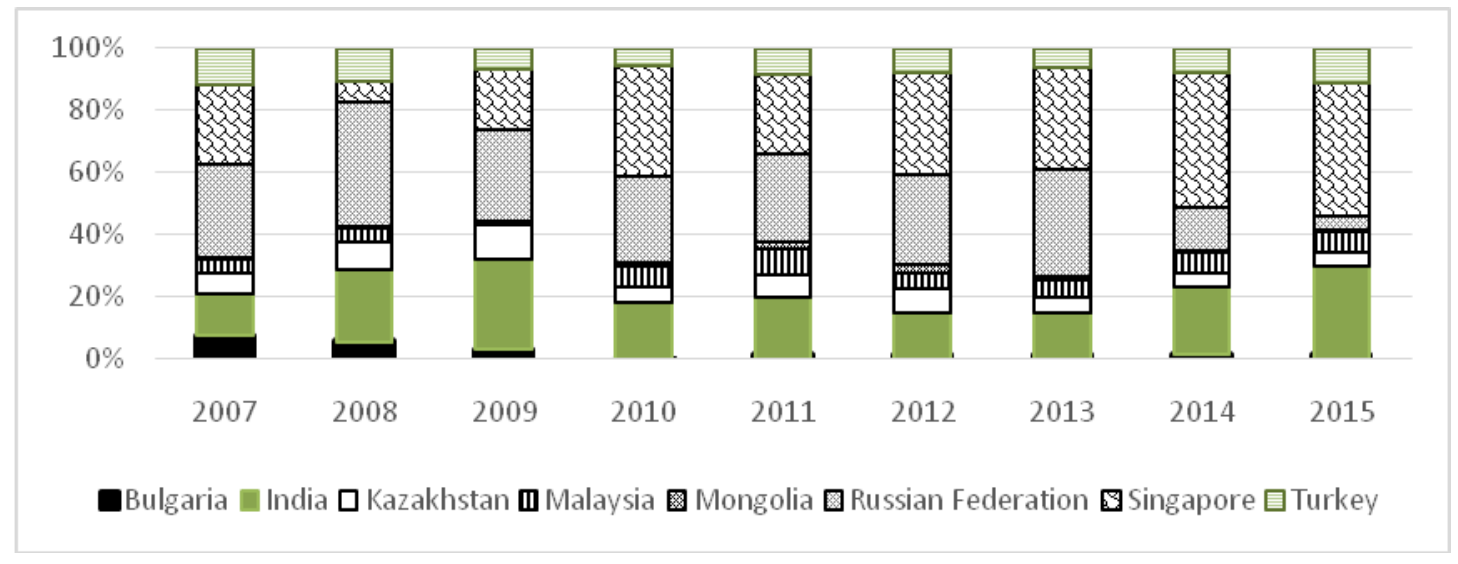


From the above analysis, it is found that the foreign direct investment business of each country develops with the development of economy. Financial transactions between countries require the development of regional financial services. The development of foreign direct investment business and other financial institutions requires the service of foreign financial settlement business to bring convenient services to the flow of financial assets in the region. $\mathrm{t}$ is the space for the development of regional financial services.

(2) Improvement of cross-border financing mechanism is the guarantee for the development of regional financial services

With the development of regional economic cooperation, cross-border financing business between countries has become more and more frequent, and the financing scale has gradually expanded. The net external debt flow of a country can well reflect the scale of its cross-border financing business. The negative value in figure 3 shows the amount of debt to be paid and the positive value shows the amount of money lent out. It can be seen from the figure, China has lent more money to the outside world, with a maximum value of $\$ 328,135$ million. Except for negative values in 2008 and 2015, it is positive that China is one of the major capital exporters. To some extent, it shows China's strong support for the economic development of countries along the "One Belt One Road". Second, Russia has a relatively large net foreign debt flow. The amount of debt service and loan amount are relatively large, which indicates that the cross-border financing volume of the country is relatively large. Once again, Turkey, India, Bulgaria, Mongolia and Kazakhstan all carry out cross-border financing in varying degrees to supplement domestic financing.

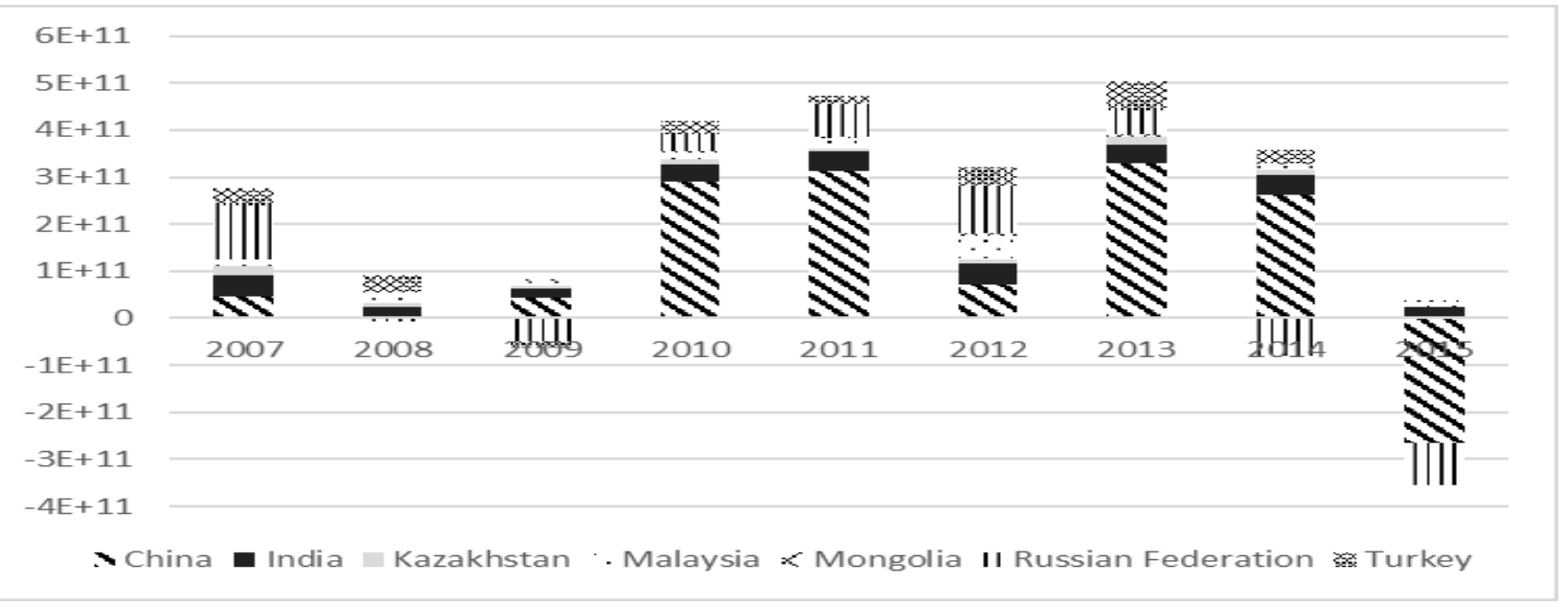

Note: Because there is no statistical data on the net external debt of Singapore in the World Bank data, the situation in Singapore is not shown in the figure. Figure 3 the net external debt flow of countries along the B\&R Source: world Bank official website data collection

In an open economy, cross-border financing is an effective supplement to domestic financing, but it is also an important factor affecting the operation of a country's economic and financial security. In particular, the largescale currency exchange activities triggered by cross-border financing of foreign currencies are often the last straw to bring down the entire national economy. This is why the management of cross-border financing is a problem for many countries. From the aftermath of the financial crisis, the problems such as high leverage and structural imbalances caused by cross-border financing are often the main causes of the financial crisis caused by improper management of cross-border financing activities. Cross-border financing business between countries is a dynamic activity. The hidden risks are difficult to observe, and the information collection of the financing subject requires a great deal of cost. In order to realize the safe and healthy development of cross-border financing business, countries are highly coordinated in policy systems and establish the dynamic transmission mechanism of financing activities.

(3) "big data" is an important resource for the development of regional financial services

Big data gathers a lot of information from many customers, including the consumption of personal basic living products, transaction records of personal financial products, financial products service records, supplier management and so on. Using Internet technology to screen big data, it is very good to analyze the behavior characteristics of consumers. 
Which can provide valuable reference for the product innovation of financial institutions? With the advent of big data era, the financial services of the financial industry will be transformed into networked services and virtualization services to provide customers with a variety of online financial transactions in the future. Through the use of big data, Analyze the data flow of financial transactions and customer demand characteristic, better targeted to provide relevant financial products, meet the needs of diverse, puts forward a new management mode and operation mode. Using big data resources is a necessary condition for the development of financial services in the future.

(4) Internet development is the technical basis for the development of regional financial services

With the rapid development of Internet technology, it has infiltrated various fields and promoted the development of different fields in different industries. Similarly, the convergence of the Internet and the financial sector has increased the efficiency of financial services and reduced the cost of financial transactions and management. It has enhanced the liquidity of financial assets, improved the financial supply and opened up the market of financial services.

In the traditional financing mode, because of the lack of customer related data information, financial institutions in order to effectively control risk, adhering to the "pledge or guarantee "financing concept, make loans after due diligence regular process. And the Internet technology is so developed today, on the one hand, Banks can cooperate with third-party receiving institutions, core enterprises of the supply chain, e-commerce enterprises, etc. and use the improvement transaction information, personal credit information and other information to complete the enterprise credit of the enterprise credit evaluation system with magnum, high speed and low cost. On the other hand, Banks provide customers with diversified financial products through Internet technology.

\section{Challenges of regional financial development under the background of $B \& R$}

(1) Regional financial service model innovation and financial risks

In the process of its development, regional finance continuously creates new financial products, financial services and financial instruments due to the competition mechanism and market mechanism to meet the new demands of the social economy, change the original mechanism and structure of the financial market, and make the financial system change. The innovation of regional financial service mode changed the speed of financial development and promoted the development of regional finance. At the same time, the new financial instruments derived from the innovation of regional financial service mode can distort the financial market mechanism, increase risk in financial markets or create new financial risks. The innovative new financial instruments have a lot of concealment, and it is difficult to find the negative effects before they are used. There are many financial derivatives have emerged with the rapid development of economy and finance. The new service model of regional finance and the overuse of new financial instruments easily lead to excessive virtualization of finance. It can easily lead to the separation of finance and real economy and raise financial risk. With the expansion of economic and financial cooperation under the $B \& R$, financial institutions have increased their business contacts and enhanced their business relations among different countries. The high correlation between regional financial institutions promotes the development of regional finance on the one hand and easy to influence each other on the other hand. The problems of financial institutions in any of the interconnected financial institutions will have a certain impact on the financial institutions of other associated countries, even cause large fluctuations in regional finance, and disrupt the stable development of regional financial markets. In the development of regional finance, it is a major challenge for regional financial development that strengthens the prevention ability of financial risks, enhance the monitoring ability of financial risks and ensure the stability of regional finance.

(2) Regional financial services and technological innovation capabilities

Under the background of B\&R strategy, financial cooperation between regions is more frequent, but it is difficult to establish a unified financial service system due to different levels of economic and financial development. And each country's technical innovation ability has different in support for financial services. The development of regional financial services among countries has put forward new requirements for its technological innovation ability. We can see the level of regional economic and financial development from the proportion of exports of goods and services to gross national product. Its services include financial industry, logistics industry, tourism industry and information technology. It can indicate the characteristics of financial service level to a certain extent. With the development of the regional economy, the economic and financial services transactions between the regions are growth. 
It can be seen from the table 1 that Singapore and Malaysia have the highest share of exports of goods and services. Second, Bulgaria, Kazakhstan and Mongolia are in high level, its exports of goods and services occupy about $50 \%$ to $60 \%$.Again, China, India, Russia and Turkey are in a low state. Its exports of goods and services occupy about $20 \%$ to $30 \%$ of GDP. Although exports of goods and services vary from country to country, but there is a same trend that the proportion of goods and services to GDP in some countries has declined slightly due to the downturn in the international economic environment. However, each country maintained a certain export ratio between 2007 and 2015, with a relatively small fluctuation range. The development of regional financial development in this country requires the support of technology to develop faster and more safely.

Table 1 goods and service exports of countries along the B\&R share of GDP (\%)

\begin{tabular}{l|l|l|l|l|l|l|l|l|l}
\hline & 2007 & 2008 & 2009 & 2010 & 2011 & 2012 & 2013 & 2014 & 2015 \\
\hline Bulgaria & 51.97 & 52.30 & 42.41 & 50.18 & 59.07 & 60.80 & 64.65 & 65.01 & 64.11 \\
\hline china & 35.95 & 32.02 & 24.36 & 26.27 & 26.49 & 25.41 & 24.50 & 24.08 & 22.09 \\
\hline India & 21.01 & 24.27 & 20.62 & 22.59 & 24.54 & 24.52 & 25.32 & 22.91 & 19.94 \\
\hline Kazakhstan & 49.31 & 57.15 & 41.84 & 44.24 & 46.46 & 44.11 & 38.62 & 39.34 & 28.46 \\
\hline Malaysia & 106.17 & 99.50 & 91.42 & 86.93 & 85.26 & 79.30 & 75.63 & 73.79 & 70.90 \\
\hline Mongolia & 59.61 & 54.02 & 50.28 & 46.68 & 52.55 & 43.57 & 38.89 & 52.25 & 45.68 \\
\hline Russia & 30.16 & 31.31 & 27.94 & 29.22 & 28.25 & 27.38 & 26.63 & 27.54 & 29.53 \\
\hline Singapore & 214.74 & 230.27 & 191.88 & 199.26 & 200.93 & 195.39 & 192.35 & 192.11 & 176.49 \\
\hline Turkey & 22.32 & 23.91 & 23.32 & 21.21 & 23.98 & 26.30 & 25.64 & 27.88 & 27.96 \\
\hline Source:
\end{tabular}

Source: world bank official website

Due to the differences in the economic development level of countries along the B\&R, the level of technological development is also different. The level of $R \& D$ expenditure in a country reflects a country's technological innovation ability. Research and development expenditure refers to the regular expenditure and capital expenditure of systematic and innovative work. As shown in figure 4 below, Singapore's R\&D expenditure has the highest proportion of GDP, reaching $2.62 \%$ at the peak. Secondly, China's R\&D expenditure share of GDP is relatively high, and there is a trend of increasing year by year, from $1.38 \%$ in 2007 to $2.05 \%$ in 2014 .Russia ranks third in R\&D spending. India and Turkey have similar R\&D spending. Because of the availability of data in India, we just collect data from 2007 to 2011.During this period India's R\&D expenditure fluctuated between $0.79 \%$ and $0.84 \%$.And there's a growing trend in Turkey, it rose from $0.72 \%$ in 2007 to $1.01 \%$ in 2014.Malaysia is the thirdworst $R \& D$ spender in the nine countries. There is increasing trend, increase from $0.79 \%$ in 2008 to $1.09 \%$ in 2012, the rate of growth is slow. Mongolia's R\&D expenditure is fluctuating between $0.23 \%$ and $0.34 \%$, and $\mathrm{R} \& \mathrm{D}$ spending is relatively low. Kazakhstan has the lowest $\mathrm{R} \& \mathrm{D}$ spending in the nine countries, with a range of $0.17 \%$ to $0.23 \%$.From the above data analysis, it is found that different countries have different levels of technological development, so their financial development support is different. Regional financial support is needed in the process of regional economic development. And the need of regional finance development brings new challenge to technological innovation ability.
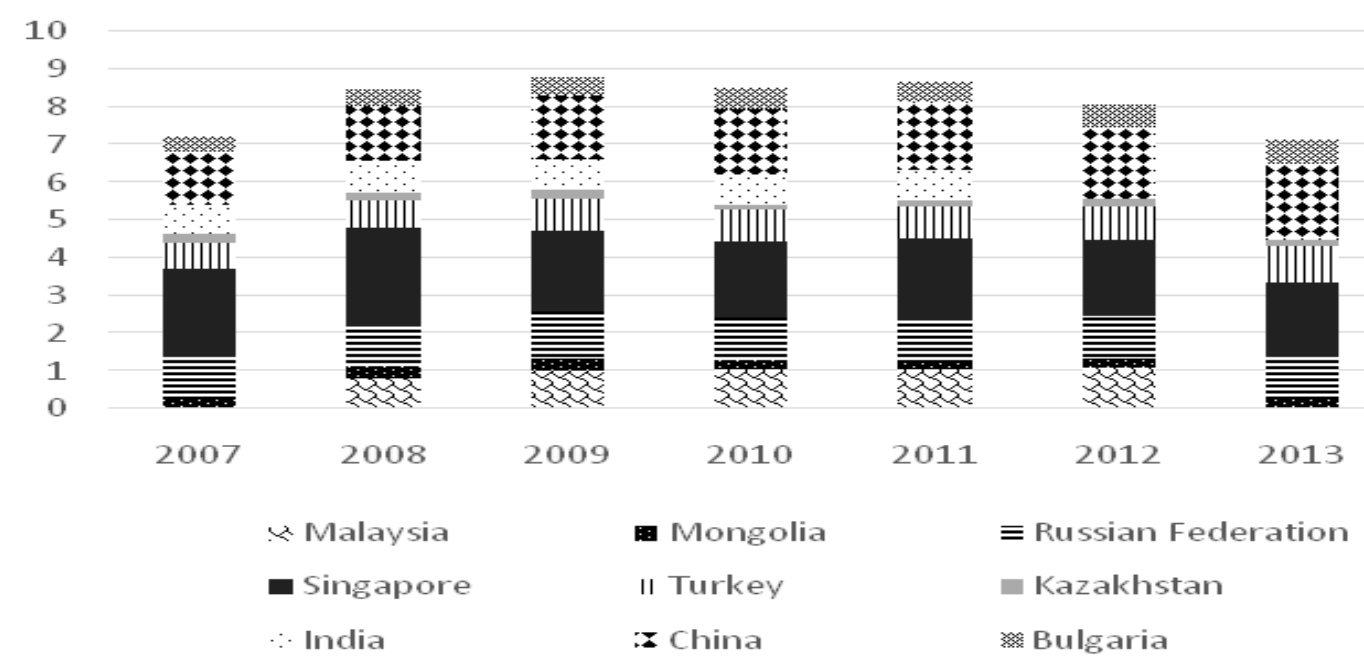

Figure 4 The share of R\&D expenditure of GDP

Source: world bank official website 


\section{(3) Regional financial innovation and regional trade fluctuations}

As a bridge between different economies, foreign trade has a close and complicated relationship with regional financial development. The innovation of regional finance has its implied risk, and the efficiency and effect of financial innovation products are different in different regions, different social environments and different economic development environments. There is a special relationship between regional financial innovation and regional trade. In a rapidly developing country or region, on the one hand, with the development of economic growth, domestic consumption demand and investment demand increase. the expending scale of enterprises in different industries providing jobs and reducing domestic employment pressure. There is increasing the demand for foreign products by individuals and enterprises, thus increasing the import growth rate with the increase of domestic consumption demand and people's consumption diversification and the domestic enterprises introduced advanced equipment. As figure 5 shows, after the 2008 financial crisis, economies gradually recovered. In particular, China's economy has been developing rapidly, and its import volume has been increasing, reaching 195,92.23 billion dollars in 2014.On the other hand, with the rapid development of national or regional economy, domestic product supply not only meets domestic demand, but also satisfy foreign demand. Thus, increase exports of countries and regions. As the chart below shows, national export quotas fluctuate with the development of the economy. After the financial crisis in 2008, China's exports increased year by year, and by 2014 the value of exports reached $\$ 234.229$ billion. China's exports are still larger than imports, and China is clearly a major exporter. In general, economic expansion will also boost export growth in the region or country. The expansion of foreign trade caused by this economic development will bring new product service requirements to regional finance and promote regional financial innovation.

Figure :

Source: world bank official website

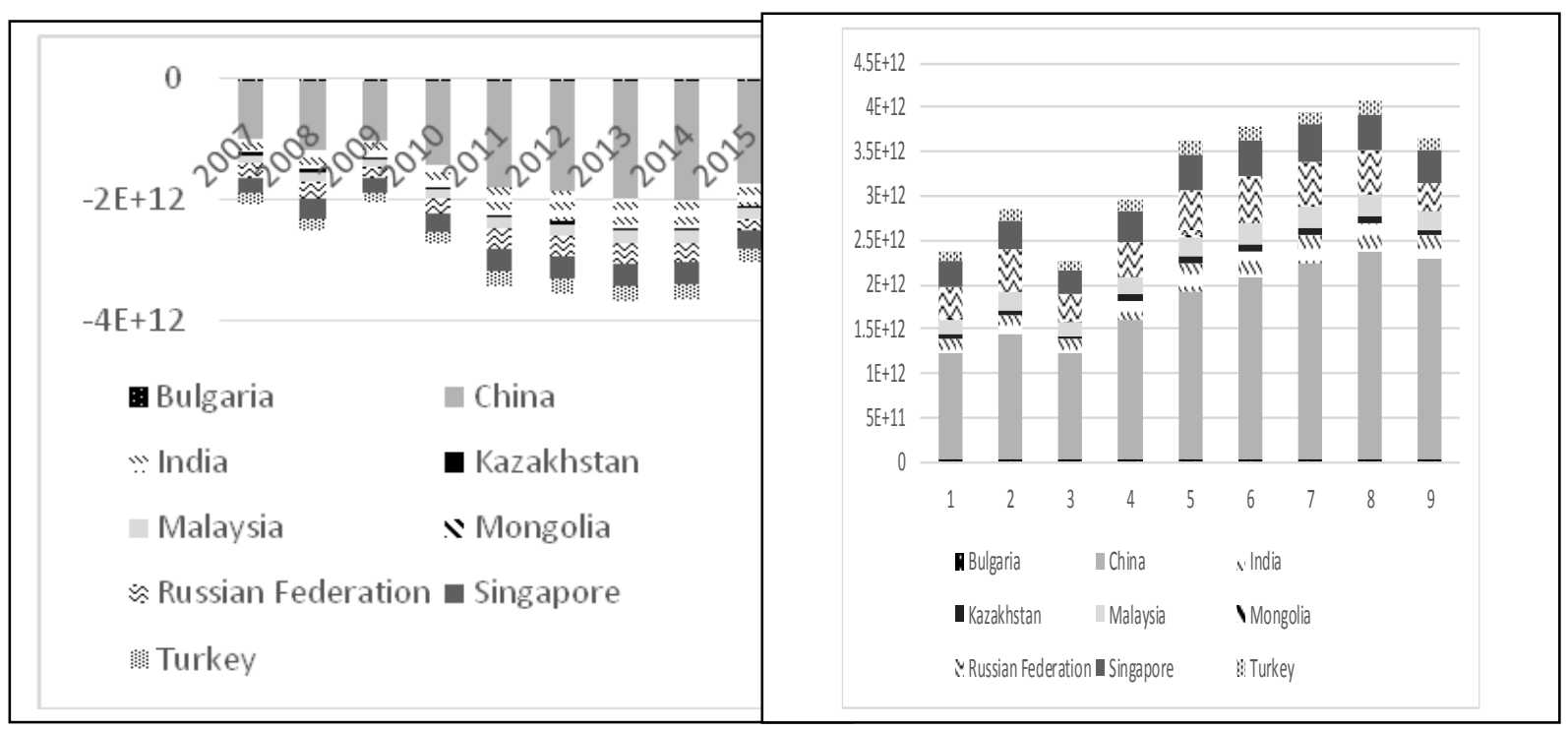

Regional financial innovation is a double-edged sword. Financial innovation can promote the development of regional economy. It also can disrupt the regional economic market order, and could even cause financial crisis, which will bring the country and the region into recession. Many countries bear the hidden risks of financial innovation products in the process of using new financial innovations. This kind of risk is very difficult to observe with the naked eye, and in the process of use, due to different economic environment and other factors, its ultimate function is different. If the risk exposure of regional financial innovation products is out of control, it will distort the financial market mechanism. At the same time, it affects the economic and trade markets of the country and region, cause trade fluctuation.

\section{Suggestions on regional financial development under the background of $B \& R$}

Financial innovation is a new combination of financial production factors or production conditions to introduce the financial system and improve the allocation efficiency of financial resources and the efficiency of financial operation. 
Through the reconfiguration of financial markets and financial institutions, the sensitivity of information is continuously enhanced and the financial instruments' diversification of financial risk function keeps improving. In the process of economic integration, the requirements of financial innovation are constantly improved. In particular, in the $B \& R$ development strategy, financial innovation is the key to the cooperation and common development between countries along the B\&R.As we all know, the countries along the B\&R are mostly developing countries with relatively weak economic strength. The foundation of the cooperation with those countries in manufacturing and service industry lies is the innovation of financial service model. In addition, in the process of RMB internationalization, the development of offshore financial market is an important channel to attract financial products and investors. Furthermore, the supply-side structural reform puts forward an efficient financial supervision system for the allocation of financial resources and new requirements of reduce systemic risk and regional risks

\section{(1) Innovation of financial services method}

The $B \& R$ development strategy needs to be innovated, and the regional finance under the $B \& R$ strategic background needs innovative development. According to the macro economic development situation and the combination of macro financial policies, the different regions can enhance their financial innovation ability and promote the coordinated development of regional economy. At the same time, meet the requirements of financial services and the level of economic development to realize the regional financial development goals. With the development of our country's social economy, China's position in the international market has been continuously improved. China needs to continuously realize the innovation of financial products and provide financial support for the financial development of countries along the $B \& R$ to realize the coordinated development of regional finance.

In the aspect of financial business innovation, financial cooperation between different countries or regions needs to be market-oriented and expanding convenient and safe operation channels for funds to realize the rational allocation of financial capital between different economies. Regional financial institutions carry out various business transactions such as bonds and use the network platform to realize the integration of transaction forms. The expansion of regional cooperation among various financial services enables limited financial resources and financial capital to maximize efficiency between different regions and achieve win-win cooperation among regions.

In terms of financial institution innovation, China uses Internet technology to establish Internet financial institutions in all countries along the B\&R. With the support of Internet security management technology, china need to promote regional financial cooperation and innovative regional financial services comprehensively too make financial institutions more open and promote the trans-regional development of financial services. Financial institutions can take advantage of the Internet financial institutions, to speed up the construction of online financial business, through regional financial policy support, strengthen strategic support, provide favorable conditions for the coordinated development of regional finance. In the financial market innovation, the regional financial market appeared the phenomenon of mergers and acquisitions. In the innovation mode, financial the establishment of regional financial should guide market center and optimize the talent construction of financial industry. Optimize financial institutions and improve financial services, through mergers and acquisitions.

(2) improve the comprehensive coordination mechanism for financial services

Regional financial development is difficult to achieve coordinated development between regions due to different levels of financial development in different regions. Each region should make reasonable use of the comparative advantage conditions of the region, develop the local economy rapidly, to promote the further development of the financial industry and reduce the gap of the financial development among different area. Establish a regional financial development mechanism and effectively promote the coordinated development of regional finance. Under the background of $\mathrm{B} \& \mathrm{R}$ development strategy, regional financial institutions need to establish efficient capital operation system to improve the coordination mechanism of regional finance. The economic development level of countries along the B\&R is different. The low level of economic development in most countries leads to differences in financial policies, financial markets and financial services in different regions.

Regional finance needs to establish an efficient payment and clearing system to provide safe, efficient and convenient fund clearing services for regional financial development. Due to the different levels of economic development in different regions, the network technology and infrastructure construction are also different. 
We need to cooperate with various government departments to provide financial enterprises with basic public networks and information exchange platforms and accelerate the development of innovative financial products such as online banking and e-commerce. To establish a comprehensive financing service system between regions, to provide customers with the possibility of cross-district clearing and consultation and achieve cross-regional flows of financial products and financial resources.

The improvement of the comprehensive coordination mechanism of financial services requires good financial system and financial cooperation between regions. The countries along the $\mathrm{B} \& \mathrm{R}$ have accelerated the economic and financial development of the region, provide a good policy environment for international financial cooperation, vigorously support regional cooperation in finance, and work together to improve the coordination mechanism for regional financial services by method of policy support.

(3) Improve the regional financial management system

There is no denying that there is a certain antagonistic relationship between financial innovation and financial regulation. In general, financial regulation imposes constraints on the innovation of financial services and financial services. At the same time, financial innovation creates uncertainty for financial regulation and even weakens the role of financial regulation. However, it cannot be ignored that financial regulation, which is constantly introduced in the process of financial innovation, has a strong impetus to financial innovation. In the practice of financial innovation in China, the innovation of financial products and financial service mode is accomplished by the policy, rather than by the innovative financial organization. As a result, the rapid development of the business and industry, which is supported by the policy, and other areas have lagged behind. Financial regulation mainly includes the reform of the concept of financial regulation, as well as the reform of financial supervision system. The important goal of B\&R development strategy is to strengthen the coordinated development of regional economy. Economic and trade security is an important link in economic cooperation, and financial security is an important guarantee for economic security. The functions of China's financial supervision institutions play an important role in financial cooperation mechanisms such as EMEAP and 10+3.At the same time, china focuses on expanding the scope of information sharing and sharing efficiency and ensure the consistency of policy coordination and supervision in the process of cooperation. In the process of deepening the regional financial supervision and regulation cooperation with $B \& R$ countries, we will jointly build an efficient financial security supervision mechanism to form a safe and effective investment and financing environment. Among them, the regional financial risk regulation focuses on the improvement of the ability to accurately predict and ensure the sustainable and safe operation of regional finance. In addition, the system and function of the risk early warning system are designed to reduce the financial risk of $B \& R$ countries and reduce the financial risk to a reasonable range of forecast and controllable.

\section{References}

Colwell, R. 1991. The Performance of major British banks, 1970-90. Bank of England Quarterly Bulletin, 31 (4), pp.508-551

Danton, G. 1992. Major international banks performance: 1980-91. Bank of England Quarterly Bulleting, 32 (3), pp.288-297.

Gorton, G., Rosen, R. 1995. Corporate control portfolio choice and the decline of banking. The Journal of Finance L (5), pp.1377-1420.

Harrington, J.W., Warf, B. 1995. Industrial Location, Principles, Practice and Policy. Routledge, London pp.212220.

Javetski, B., Glasgall, W., Dwyer, P., Lindorff, D., 1995. Swiss Bank Corp. reinvents itself, Business Week, 6th March, No. 3398-728, pp. 54-57.

Huoxuewu, zhangjing and Cai yiping. 2016. on creating a new pattern of trade finance business -- based on the "One Belt One Road" strategy background. rural finance research, October, pp.24-29.

Xia caiyun, he rui. 2015."One Belt One Road" strategic regional financial cooperation research. financial innovation, July, 317, pp.34-38. 